Струтинська Ірина, кандидат економічних наук, доцент, Тернопільський національний технічний університет ім. І. Пулюя кафедра комп'ютерних наук м. Тернопіль; ORCID ID 0000-0001-5667-6569 e-mail: ringtons999@gmail.com

\author{
https://doi.org/10.29038/2411-4014-2019-04-93-100
}

\title{
ЦИФРОВА ГРАМОТНІСТЬ ЛЮДСЬКОГО КАПІТАЛУ БІЗНЕС-СТРУКТУР
}

Останнє десятиліття характеризується стрімким розвитком інформаційних технологій, які кардинально змінюють життя суспільства. Економічні відносини стали надзвичайно залежними від інфраструктурного інформаційного забезпечення, соціальні відносини перейшли із сфери виключно прямої взаємодії до територіально та часово віддаленої завдяки можливостям цифрового простору.

Такі радикальні перетворення вимагають нового підходу до розуміння наслідків цих процесів, вмінь адаптувати цифрові технології до сучасних вимог суспільства та бізнесу.

Тому метою даної статті $€$ розкрити зміст та особливості впровадження концепції цифрових компетентностей, визначити перспективи і переваги формування компетентісного підходу в умовах інформаційного суспільства. Провести аналіз «рамки цифрової компетентності» та розробити рамки цифрових компетенцій для людського капіталу бізнес-структур.

Ключові слова: цифрова компетентність, цифрова грамотність, професійна компетентність, інформаційне суспільство, розвиток цифрових компетенцій.

Струтинська Ирина, кандидат экономических наук, доцент, Тернопольский национальный технический университет им. И. Пулюя кафедра компьютерных наук м. Тернополь

\section{ЦИФРОВАЯ ГРАМОТНОСТЬ ЧЕЛОВЕЧЕСКОГО КАПИТАЛА БИЗНЕС- СТРУКТУР}

Последнее десятилетие характеризуется стремительным развитием информационных технологий, которые кардинально меняют жизнь общества. Экономические отношения стали чрезвычайно зависимыми от инфраструктурного информационного обеспечения, социальные отношения перешли из сферы исключительно прямого взаимодействия с территориально и по времени удаленной благодаря возможностям цифрового пространства. Такие радикальные преобразования требуют нового подхода к пониманию последствий этих процессов, умений адаптировать цифровые технологии с современными требованиями общества и бизнеса.

Поэтому целью данной статьи является раскрыть содержание и особенности внедрения концепции цифровых компетенций, определить перспективы и преимущества формирования компетентностного подхода в условиях информационного общества. Провести анализ «рамки цифровой компетентности» и разработать рамки цифровых компетенций для человеческого капитала бизнес-структур.

Ключевые слова: цифровая компетентность, цифровая грамотность, профессиональная компетентность, информационное общество, развитие цифровых компетенций.

Iryna Strutynska,

PhD Candidate of Economic Sciences, Associate Professor, Ternopil Ivan Puluj National Technical University Computer Science Department Ternopil, Ukraine

\section{DIGITAL LITERACY OF HUMAN CAPITAL BUSINESS STRUCTURES}


The last decade has been characterized by the rapid development of information technologies that are fundamentally changing society. Economic relations have become extremely dependent on infrastructural information support, social relations have shifted from the sphere of exclusively direct interaction to territorially and temporally distant due to the possibilities of digital space.

Such radical transformations require a new approach to understanding the consequences of these processes, the ability to adapt digital technologies to the contemporary requirements of society and business.

Therefore, the purpose of this article is to expose the content and features of implementing the concept of digital competencies, to identify the perspectives and benefits of developing a competency-based approach in an information society environment. Conduct a digital competence framework analysis and develop a digital competency framework for the human capital of business entities.

The practical results are the developed framework of digital competencies for the human capital of business organizations. Reflecting the level of digital maturity of the company and the level of digital literacy of human capital.

In the digital age, it is necessary to improve the quality and effectiveness of education aimed at preparing young people for life in the digital society, acquiring relevant digital skills, digital literacy for the population and business. The increasing need to use modern computer technology in the workplace has led to the need to increase computer literacy for most professions. The digital competencies of human capital are the basis for digital transformation of business.

Keywords: digital competence, digital literacy, professional competence, information society, development of digital competencies.

Постановка проблеми та їі значення. Розвиток цифрових навичок стає однією 3 найважливіших умов для розвитку цифрового ринку будь-якої країни, оскільки прямо або опосередковано пов'язаний з усіма сферами функціонування суспільства та економіки.

Саме тому в «Концепції розвитку цифрової економіки та суспільства України на 2018-2020 роки» передбачено здійснення заходів щодо впровадження відповідних стимулів для цифровізації економіки, суспільної та соціальної сфер, усвідомлення наявних викликів та інструментів розвитку цифрових інфраструктур, набуття громадянами цифрових компетенцій.

Проте, на сьогодні в Україні не існує бачення та жодної державної ініціативи, програми, стратегічного документа, спрямованих на створення комплексної національної системи розвитку цифрової грамотності. На державному рівні відсутні інструменти моніторингу та оцінки цифрових компетенцій [1]. Відсутні також комплексні методології для проведення необхідних досліджень ситуації у сфері розвитку цифрових навичок і компетенцій, що унеможливлює розробку методології вимірювання та впровадження незалежної сертифікації рівня цифрових навичок відповідно до потреб ринку праці. Методика збирання статистичних даних державними органами статистики є не дуже досконалою для проведення належного аналізу ситуації у сфері розвитку цифрових навичок $\mathrm{i}$ компетенцій.

Аналіз останніх досліджень і публікацій. Питанню розвитку цифрових компетенцій присвячені праці В. С. Куйбіди, О. М. Петроє, Л. І. Федулова, Г. О. Андрощука [1]. Вчені ініціюють вирішення проблеми розробки методології оцінки рівня цифрової грамотності суспільства. Проблемамам та перспективам гармонізації цифрового ринку України з ринками ЄС та країн СхП присвячені праці таких вчених: В. Ночвай, М. Корявець, І. Кульчицький, Л. Олексюк, О. Приходько, К. Гороховський, В. Грига [2]. Вони також розглядають питання гармонізації цифрових навиків. Проте, проблемам та перспективам розвитку цифрової грамотності людського капіталу бізнесструктур не приділено достатньої уваги.

Мета і завдання статті. Метою даної статті є розкрити зміст та особливості впровадження концепції цифрових компетентностей, визначити перспективи i переваги формування компетентісного підходу в умовах інформаційного суспільства. Провести аналіз «рамки цифрової компетентності» та розробити рамки цифрових компетенцій для людського капіталу бізнес-структур.

Викладення основного матеріалу. Врахування вимог часу в напрямку розширеного розуміння та використання інформаційних технологій у повсякденному та професійному житті, у бізнеспроцесах та державному управління є основою до поступального розвитку в кінцевому підсумку національної економіки.

Міжнародна комісія Ради Європи у своїх документах розглядає поняття компетентності як загальні, або ключові, вміння, базові вміння, фундаментальні шляхи навчання, ключові кваліфікації, крос-навчальні вміння або навички, ключові уявлення, опори або опорні знання [1]. 
«Цифрова» компетентність (або «Цифрова» грамотність) визнана ЄС однією 38 ключових компетенцій для повноцінного життя та професійної діяльності. У 2017 році ЄС представив оновлений фреймворк Digital Competence (DigComp 2.1) [4], що складається з основних 5 вимірів цифрових компетенцій, 8 рівнів (блоків) розвитку цифрових компетенцій (усього 21 компетенції, що до них входить (табл. 1).

Таблиия 1

Рамки цифрових компетенцій (Digital Competence (DigComp 2.1) *

\begin{tabular}{|c|c|c|c|c|c|c|c|c|}
\hline \multicolumn{9}{|c|}{ Цифрові компетенцій СC (DigComp 2.1) для суспільства } \\
\hline DigComp 1.0 & \multicolumn{2}{|c|}{ Базовий } & \multicolumn{2}{|c|}{ Середній } & \multicolumn{2}{|c|}{ Вищий } & \multicolumn{2}{|c|}{ Експертний } \\
\hline $\begin{array}{c}\text { Рівень DigComp } \\
2.1\end{array}$ & \multirow[t]{2}{*}{ Рівень 1} & \multirow[t]{2}{*}{ Рівень 2} & \multirow{2}{*}{ Рівень 3} & \multirow[t]{2}{*}{ Рівень 4} & \multirow[t]{2}{*}{ Рівень 5} & \multirow[t]{2}{*}{ Рівень 6} & \multirow[t]{2}{*}{ Рівень 7} & \multirow[t]{2}{*}{ Рівень 8} \\
\hline Назва компетенцій & & & & & & & & \\
\hline $\begin{array}{l}\text { 1.Інформаційна } \\
\text { грамотність та } \\
\text { грамотність щодо } \\
\text { роботи } 3 \text { даними. }\end{array}$ & \multicolumn{8}{|c|}{$\begin{array}{l}\text { 1.1. Вміння шукати, фільтрувати дані, інформацію та цифровий контент. } \\
\text { 1.2. Вміння оцінювати дані, інформацію та цифровий контент. } \\
\text { 1.3. Вміння використовувати та управляти даними, інформацією та цифровим контентом. }\end{array}$} \\
\hline $\begin{array}{l}\text { 2. Комунікація та } \\
\text { взаємодія. }\end{array}$ & \multicolumn{8}{|c|}{$\begin{array}{l}\text { 2.1 Вміння спілкуватися через використання цифрових технологій. } \\
2.2 \text { Вміння ділитися інформацією завдяки використанню цифрових технологій. } \\
2.3 \text { Вміння контактувати із суспільством, користуватися державними та приватними послугами завдяки } \\
\text { використанню цифрових технологій. } \\
2.4 \text { Вміння взаємодіяти завдяки використанню цифрових технологій. } \\
2.5 \text { Знання «нетикету» (від англ. network та etiquette), тобто володіння правилами поведінки та етикету } \\
\text { в цифровому середовищу. } \\
2.6 \text { Управління цифровою ідентичністю, тобто вміння створювати та управляти аккаунтами. }\end{array}$} \\
\hline $\begin{array}{l}\text { 3. Цифровий } \\
\text { контент. }\end{array}$ & \multicolumn{8}{|c|}{$\begin{array}{l}3.1 \text { Створення цифрового контенту. } \\
3.2 \text { Вміння змінювати, покращувати, використовувати цифровий контент задля створення нового } \\
\text { контенту. } \\
3.3 \text { Обізнаність щодо авторських прав та політики ліцензування відносно даних, інформації та } \\
\text { цифрового контенту. } \\
3.4 \text { Програмування, тобто вміння писати програмний код. }\end{array}$} \\
\hline 4. Безпека. & \multicolumn{8}{|c|}{$\begin{array}{l}\text { 4.1 Вміння захистити пристрої та контент, знання заходів безпеки, розуміння ризиків та загроз. } \\
4.2 \text { Захист персональних даних та приватності. } \\
4.3 \text { Охорона здоров’я, тобто знання та навички для збереження свого здоров’я та інших з точки зору як } \\
\text { екології використання цифрових технологій, так і ризиків, загроз безпеці громадян. } \\
4.4 \text { Захист навколишнього середовища, тобто розуміння впливу цифрових технологій на екологію, } \\
\text { навколишнє середовище, з точки зору їх утилізації, а також їх використання, що може нанести шкоду, } \\
\text { наприклад, об’єктам критичної інфраструктури і т. д. }\end{array}$} \\
\hline $\begin{array}{l}\text { 5. Вирішення } \\
\text { проблем. }\end{array}$ & \multicolumn{8}{|c|}{$\begin{array}{l}5.1 \text { Вміння вирішувати технічні проблеми, що виникають із комп’ютерною технікою, програмним } \\
\text { забезпеченням, мережами і т. д. } \\
5.2 \text { Вміння визначати потреби та знаходити відповідні технічні рішення, або кастимізувати цифрові } \\
\text { технології до власних потреб. } \\
5.3 \text { Креативне користування, або вміння завдяки цифровим технологіям створювати знання, процеси та } \\
\text { продукти, індивідуально або колективно, з метою вирішення повсякденних життєвих та професійних } \\
\text { проблем і т. д. } \\
5.4 \text { Вміння самостійно визначати потребу в отриманні додаткових нових цифрових навичок. }\end{array}$} \\
\hline Складність задач & $\begin{array}{c}\text { Прості } \\
\text { задачі }\end{array}$ & \begin{tabular}{|c|} 
Прості \\
задачі
\end{tabular} & \begin{tabular}{|c|} 
Чітко \\
визначені, \\
рутинні \\
задачі, \\
прямолінійн \\
і проблеми
\end{tabular} & \begin{tabular}{c|c|} 
Задачі та \\
чітко \\
визначені і \\
нерутинні \\
проблеми
\end{tabular} & $\begin{array}{c}\text { Різні задачі та } \\
\text { проблеми } \\
\end{array}$ & $\begin{array}{l}\text { Найбільш } \\
\text { відповідні } \\
\text { задачі }\end{array}$ & $\begin{array}{c}\text { Вирішення } \\
\text { складних } \\
\text { проблем з } \\
\text { обмеженими } \\
\text { розв'язками }\end{array}$ & $\begin{array}{c}\text { Вирішення } \\
\text { складних } \\
\text { проблем з } \\
\text { багатьма } \\
\text { взаємодіючими } \\
\text { факторами }\end{array}$ \\
\hline Автономність & $\begin{array}{c}3 \\
\text { допомогою }\end{array}$ & \begin{tabular}{c|} 
Самостійно, \\
3 допомогою \\
за потреби
\end{tabular} & Самостійно & \begin{tabular}{|c|} 
Самостійн \\
о та \\
відповідно \\
до власних \\
потреб
\end{tabular} & $\begin{array}{c}\text { Допомо } \\
\text { га іншим }\end{array}$ & $\begin{array}{c}\text { Може } \\
\text { адаптуватис } \\
\text { ь до інших у } \\
\text { складних } \\
\text { контекстах }\end{array}$ & \begin{tabular}{|c|} 
Інтеграція \\
для внеску в \\
професійну \\
практику та \\
допомоги \\
іншим \\
\end{tabular} & $\begin{array}{c}\text { Пропонування } \\
\text { нових ідей та } \\
\text { процесів для } \\
\text { сфери }\end{array}$ \\
\hline $\begin{array}{c}\text { Когнітивний } \\
\text { домен }\end{array}$ & $\begin{array}{c}\text { Запам'ятову } \\
\text { вання }\end{array}$ & $\begin{array}{c}\text { Запам'ятову } \\
\text { вання }\end{array}$ & Розуміння & Розуміння & Застосування & Оцінювання & Творчість & Творчість \\
\hline
\end{tabular}

*Джерело: адаптовано автором на основі [4] 
Цифрові компетенції та їх складові:

1. Інформаційна грамотність та грамотність щодо роботи 3 даними: 1.1. Вміння шукати, фільтрувати дані, інформацію та цифровий контент; 1.2. Вміння оцінювати дані, інформацію та цифровий контент; 1.3. Вміння використовувати та управляти даними, інформацією та цифровим контентом.

2. Комунікація та взаємодія: 2.1 Вміння спілкуватися через використання цифрових технологій; 2.2 Вміння ділитися інформацією завдяки використанню цифрових технологій; 2.3 Вміння контактувати із суспільством, користуватися державними та приватними послугами завдяки використанню цифрових технологій; 2.4 Вміння взаємодіяти завдяки використанню цифрових технологій; 2.5 Знання «нетикету», тобто володіння правилами поведінки та етикету в цифровому середовищу; 2.6 Управління цифровою ідентичністю, тобто вміння створювати та управляти аккаунтами.

3. Цифровий контент: 3.1 Створення цифрового контенту; 3.2 Вміння змінювати, покращувати, використовувати цифровий контент задля створення нового контенту; 3.3 Обізнаність щодо авторських прав та політики ліцензування відносно даних, інформації та цифрового контенту; 3.4 Програмування, тобто вміння писати програмний код.

4. Безпека: 4.1 Вміння захистити пристрої та контент, знання заходів безпеки, розуміння ризиків та загроз; 4.2 Захист персональних даних та приватності; 4.3 Охорона здоров'я, тобто знання та навички для збереження свого здоров'я та інших з точки зору як екології використання цифрових технологій, так і ризиків, загроз безпеці громадян; 4.4 Захист навколишнього середовища, тобто розуміння впливу цифрових технологій на екологію, навколишнє середовище, 3 точки зору їх утилізації, а також їх використання, що може нанести шкоду, наприклад, об’єктам критичної інфраструктури і т. д.

5. Вирішення проблем: 5.1 Вміння вирішувати технічні проблеми, що виникають із комп'ютерною технікою, програмним забезпеченням, мережами і т. д.; 5.2 Вміння визначати потреби та знаходити відповідні технічні рішення, або кастимізувати цифрові технології до власних потреб; 5.3 Креативне користування, або вміння завдяки цифровим технологіям створювати знання, процеси та продукти, індивідуально або колективно, 3 метою вирішення повсякденних життєвих та професійних проблем і т. д.; 5.4 Вміння самостійно визначати потребу в отриманні додаткових нових цифрових навичок [4].

Варто розрізняти поняття цифрової грамотності (компетентостей) від умінь та навиків. Компетентність - це більш ширше поняття, ніж просто знання та уміння. Саме тому передбачає здатність задовольняти складні задачі та вимоги, залучаючи та мобілізуючи психосоціальні ресурси (включаючи вміння та навички) у певному контексті. Поєднання hard тa soft skills (професійних та особистісних навичок та умінь).

Підвищення рівня цифрових компетентностей для використання потенціалу інформаційнокомунікаційних технологій (ІКТ) є ключовим пріоритетом стратегії Європи 2020 року [7].

Її основна ініціатива «Цифрова програма для Європи» спрямована на досягнення цієї мети. Низький рівень цифрової грамотності та навичок вважається недопустимим для громадян цифрового суспільства та цифрової економіки загалом. Вона також стримує мультиплікативний ефект, який характерний для застосування інформаційно-комунікаційних технологій.

Великий потенціал IКТ може бути використаний за допомогою добре функціонуючого доброчесного циклу діяльності. Привабливий контент та послуги повинні бути доступними в оперативному та безмежному інтернет-середовищі. Це стимулює попит на більш високу швидкість i пропускну спроможність, що, в свою чергу, створює справу бізнесу для інвестицій у швидші мережі. В свою чергу розгортання та запуск більш швидких мереж відкриває шлях до інноваційних сервісів, що використовують більш високі швидкості. Цей процес проілюстровано на зовнішньому кільці 3 рис. 1 [5].

Важливим документом, відповідно до якого вибудувана системи освіти Європи стала Стратегічна рамка «Освіта і підготовка 2020» («Education and Training 2020») (ET2020) [9]. У ній визначено спільні стратегічні цілі країн Європейського Союзу в сфері підвищення рівня ефективності освіти та навчання. 


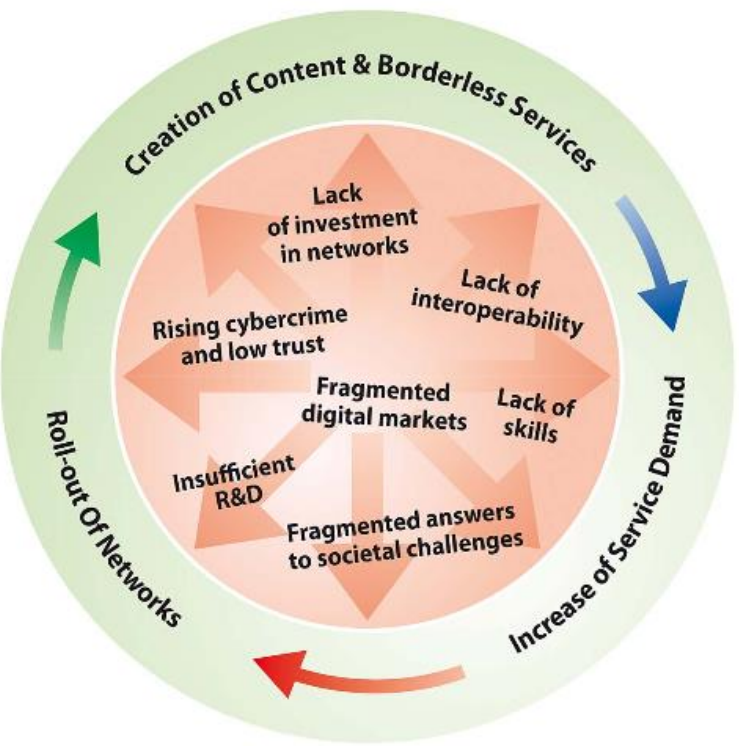

Рис. 1. Цикл иифрової економіки

Джерело: структуровано автором на основі [5]

Шість пріоритетів на період 2016-2020 роки [5-7]:

- відповідні та якісні навички та компетенції щодо працевлаштування, інновацій, активної громадянської позиції та добробуту (наприклад, творчість, почуття ініціативи та критичне мислення);

- інклюзивна освіта. Рівність, недискримінація та сприяння громадянським компетенціям;

- відкрита та інноваційна освіта та навчання, включаючи повне охоплення цифрової епохи;

- сильна підтримка освітян;

- прозорість та визнання навичок та кваліфікацій для сприяння навчанню та мобільності робочої сили (наприклад, за допомогою Європейської контрольної системи якості);

- стійкі інвестиції (включаючи вивчення потенціалу інвестиційного плану в Європі), ефективність та ефективність систем освіти та навчання.

Згідно практики $\mathrm{CC}$ «Key competences for lifelong learning» визначено вісім ключових компетенцій: 1) спілкування рідною мовою; 2) спілкування іноземними мовами; 3) математична компетентність та основні компетентності в галузі науки та техніки; 4) цифрова компетентність; 5) уміння вчитися; 6) соціальні та громадянські компетенції; 7) почуття ініціативи та підприємливості; 8) культурна обізнаність та вираження [8].

В масштабах держави покращення формування цифрових компетентностей (цифрової грамотності) у всіх сферах функціонування є джерелом підвищення рівня конкурентоспроможності країни, адже доступ до інформації, цифрова взаємодія та інтенсивність використання та вдосконалення інформаційно-комунікаційних технологій $є$ базовими елементами практично усіх глобальних індексів конкурентоспроможності. У трактуванні експертів ЮНЕСКО поняття компетентності ідентифікується як поєднання знань, умінь, цінностей та ставлень, застосовних у повсякденному житті.

За аналогією з IQ або EQ, які використовуються для вимірювання рівня загального та емоційного інтелекту, навички щодо «цифрових» технологій - це DQ (Digital Quotient), тобто «цифровий» інтелект.

DQ містить 3 рівні:

- «цифрове» громадянство, тобто використання цифрових технологій у повсякденному житті, для взаємодії один з одним, спілкування, перегляду цифрового контенту і т. д;

- «цифрова» творчість, тобто використання цифрових технологій для створення контенту, медіа, застосувань тощо; 
- «цифрове підприємництво», тобто використання цифрових технологій для бізнесу, професійної діяльності і т. ін.

Визначення цифрової грамотності (компетенцій) людського капіталу бізнес-структур $\epsilon$ надзвичайно комплексне і пояснюється сукупністю детермінант якостей процесів та властивостей, якими вони повинні характеризуватися (табл. 2).

Таблиия 2

Рамки цифрових компетенцій які відображають рівень цифрової грамотності людського капіталу в бізнес-організації *

\begin{tabular}{|c|c|c|c|}
\hline & $\begin{array}{l}\text { Рівні цифрової } \\
\text { грамотності } \\
\text { людського } \\
\text { капіталу } \\
\text { (навички та } \\
\text { компетенції) }\end{array}$ & Характеристика рівня цифрової грамотності та цифрові інструменти & $\begin{array}{c}\text { Градація } \\
\text { рівня } \\
\text { цифрової } \\
\text { грамотності }\end{array}$ \\
\hline & $\begin{array}{l}\text { Низький рівень } \\
\text { цифрової } \\
\text { грамотності }\end{array}$ & $\begin{array}{l}\text { Виконують прості задачі з допомогою або самостійно. } \\
\text { Використання ЦI: } \\
\text { Viber, Skype, Email, Word, Excel, Соціальні мережі та платформи: ФБ, Інстаграм, You } \\
\text { Tube, Телеграм та ін. (на рівні користувача). } \\
\text { Не потребують спеціальних компетенцій. }\end{array}$ & $\mathbf{0 , 2}$ \\
\hline & $\begin{array}{l}\text { Фундаментальни } \\
\text { й рівень } \\
\text { цифрової } \\
\text { грамотності }\end{array}$ & $\begin{array}{l}\text { Володіють базовими цифровими навичками. Виконують чітко визначені, рутинні та не } \\
\text { рутинні задачі, самостійно та відповідно до власних потреб. } \\
\text { Початківці SMM, SEO; знання Google doc. } \\
\text { Використання ЦI: } \\
\text { Соціальні мережі та платформи: бізнес-сторінки ФБ, Інстаграм, You Tube, Телеграм та } \\
\text { iн., сайт (на рівні професійного користувача). }\end{array}$ & $\mathbf{0 , 4}$ \\
\hline 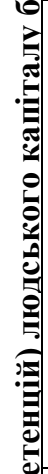 & $\begin{array}{l}\text { Проміжний } \\
\text { (перехідний) } \\
\text { рівень цифрової } \\
\text { грамотності }\end{array}$ & $\begin{array}{l}\text { Працівники вміло використовують цифрові інструменти різного рівня складності в } \\
\text { розрізі певних груп бізнес-процесів організації, за потреби можуть навчати інших. } \\
\text { Професійно виконують різні найбільш відповідні задачі та проблеми.. } \\
\text { - Базові цифрові навички та знання Gоogle Analytics, CRM. } \\
\text { - Професійні цифрові навички та знання в сфері SMM, SEO, CRM, Google Ads } \\
\text { (Google AdWords). } \\
\text { Buкористаняя ЦI: } \\
\text {-Google doc, Google Analytics, CRM-системи, чат-боти, QR-code, } \\
\text {-Соціальні мережі та платформи: ефективна робота (бізнес-сторінки ФБ, Інстаграм, } \\
\text { Үоu Тube, Телеграм та ін.); } \\
\text {-Системи управління фінансами (1С, Медок та ін.); } \\
\text { Сайт (ефективний, оборот електронної комерції (понад } 1 \% \text { від загального обороту } \\
\text { продаж та понад } 10 \% \text { В2С веб продажз загального обороту продаж у мережі Інтернет) }\end{array}$ & $\mathbf{0 , 6}$ \\
\hline 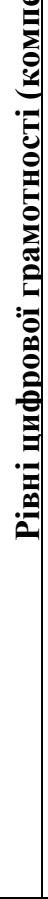 & $\begin{array}{l}\text { Прогресивний } \\
\text { рівень цифрової } \\
\text { грамотності }\end{array}$ & 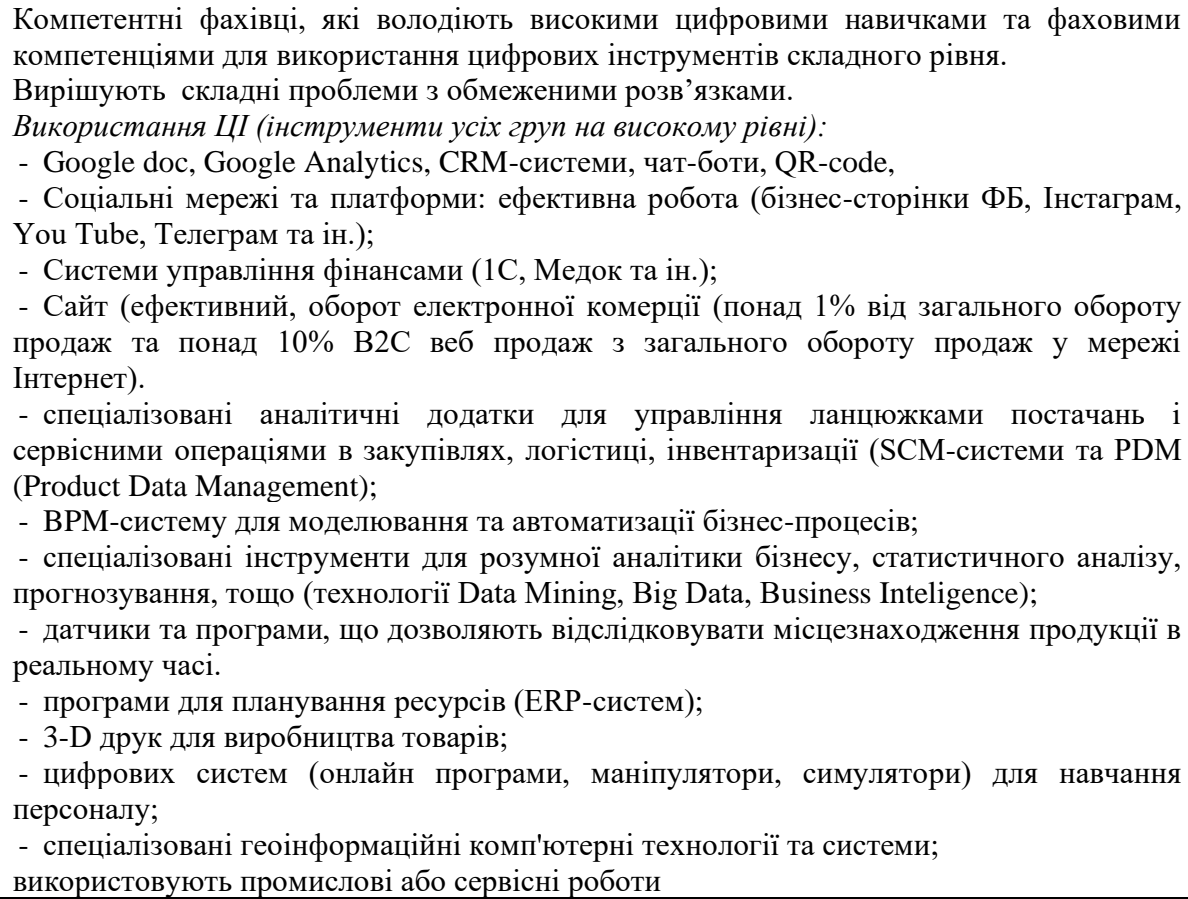 & $\mathbf{0 , 8}$ \\
\hline
\end{tabular}


* Джерело: розроблено та запропоновано автором

Загалом, вважаємо, що підвищення цифрової грамотність людського капіталу організації буде успішним лише за умови, що керівник організації зрозуміє необхідність певних трансформацій, відбудеться особистісна трансформація. Завдання керівника навчатися самому та навчати власний персонал адаптуватися до нових реалій, з мотивувати використовувати нові цифрові інструменти та використовувати усі їхні привілеї.

Вважаємо, що цифрова трансформація бізнесу виходить далеко за рамки цифрових інструментів (технологій). Процес цифрової трансформації не зможе відбутися без участі людського капіталу, а саме синхронізації та інтеграції знань, таланту, культури та організаційної структури з «цифровим» середовищем.

Висновки. Детальний аналіз документів Європейського Союзу показав, що для успішного розвитку держав-членів Свропейського Союзу, запорукою їх конкурентоспроможності, подолання економічної кризи, створення цифрової економіки необхідною умовою є підвищення якості й ефективності освіти, спрямованої на підготовку молоді до життя у цифровому суспільстві, набуття ними відповідних цифрових умінь і навичок, цифрової грамотності, мотивуючи їх до отримання ITспеціальностей. Зростання необхідності використовувати сучасну обчислювальну техніку на робочих місцях приводить до необхідності підвищення комп'ютерної грамотності для більшості професій. Розуміння, знання комп'ютерних додатків і програм стає все найбільш важливим для отримання роботи. Цифрові компетенції людського капіталу є основою для цифрової трансформації бізнесу.

\section{Джерела та література}

1. Цифрові компетенції як умова формування якості людського капіталу : аналіт. зап. / [В. С. Куйбіда, О. М. Петроє, Л. І. Федулова, Г. О. Андрощук]. - Київ : НАДУ, 2019. - 28 с. (дата звернення: 05.11.2019).

2. Проблеми та перспективи гармонізації цифрового ринку України з ринками $Є С$ та країн СхП : аналіт. Звіт / [В. Ночвай, М. Корявець, І. Кульчицький, Л. Олексюк, О. Приходько, К. Гороховський, В. Грига]: вебсайт. URL: https://cid.center/wp-content/uploads/2019/02/аналітичний-звіт-СхП.pdf (дата звернення: 05.11.2019).

3. Definition and Selection of Competencies. Theoretical and Conceptual Foundations (DESECO). Strategy Paper on Key Competencies. An Overarching Frame of Reference for an Assessment and Research Program - OECD (Draft). [Electronic resource]. - Access mode: http://www.deseco. admin.ch. (accessed 30 October 2019).

4. The Digital Competence Framework for Citizens. [Electronic resource]. - Access mode:http://publications.jrc.ec.europa.eu/repository/bitstream/JRC106281 28 October 2019).

5. A Digital Agenda for Europe. [Electronic resource]. - Access mode: https://eur-lex.europa.eu/legalcontent/EN/ALL/?uri=CELEX:52010DC0245R(01) (accessed October 2019).

6. The Entrepreneurship 2020 Action Plan. [Електронний ресурс]. - Режим доступу: https://ec.europa.eu/growth/smes/promoting-entrepreneurship/action-plan_en $\quad 30$ October 2019).

7. "Europe 2020" Strategy [Electronic resource]. - Access mode: http://ec.europa.eu/europe2020/index_en.htm (accessed

8. The Key Competences for Lifelong Learning - A European Framework. [Electronic resource]. - Access mode: https://www.erasmusplus.org.uk/file/272/download (accessed

9. Strategic framework "Education and Training 2020" (ET2020) - [Electronic resource] - Access mode: http://europa.eu/legislation_summaries/education_training_youth/general_framework/ef0016en.htm (accessed 30 October 2019). 


\section{References}

1. Tsyfrovi kompetentsii yak umova formuvannia yakosti liudskoho kapitalu : analit. zap. / [V. S. Kuibida, O. M. Petroie, L. I. Fedulova, H. O. Androshchuk]. - Kyiv : NADU, 2019. - 28 s. (data zvernennia: 05.11.2019) [in Ukrainian].

2. Problemy ta perspektyvy harmonizatsii tsyfrovoho rynku Ukrainy z rynkamy YeS ta krain SkhP : analit. Zvit / [V. Nochvai, M. Koriavets, I. Kulchytskyi, L. Oleksiuk, O. Prykhodko, K. Horokhovskyi, V. Hryha]: veb-sait. URL: https://cid.center/wp-content/uploads/2019/02/analitychnyi-zvit-SkhP.pdf (data zvernennia: 05.11.2019) [in Ukrainian].

3. Definition and Selection of Competencies. Theoretical and Conceptual Foundations (DESECO). Strategy Paper on Key Competencies. An Overarching Frame of Reference for an Assessment and Research Program - OECD (Draft). [Electronic resource]. - Access mode: http://www.deseco. admin.ch. (accessed 30 October 2019) [in English].

4. The Digital Competence Framework for Citizens. [Electronic resource]. - Access mode:http://publications.jrc.ec.europa.eu/repository/bitstream/JRC106281 (accessed 28 October 2019) [in English].

5. A Digital Agenda for Europe. [Electronic resource]. - Access mode: https://eur-lex.europa.eu/legalcontent/EN/ALL/?uri=CELEX:52010DC0245R(01) (accessed 28 October 2019) [in English].

6. The Entrepreneurship 2020 Action Plan. [Elektronnyi resurs]. - Rezhym dostupu: https://ec.europa.eu/growth/smes/promoting-entrepreneurship/action-plan_en (accessed 30 October 2019) [in English].

7. "Europe 2020" Strategy [Electronic resource]. - Access mode: http://ec.europa.eu/europe2020/index_en.htm (accessed 30 October 2019) [in English].

8. The Key Competences for Lifelong Learning - A European Framework. [Electronic resource]. - Access mode: https://www.erasmusplus.org.uk/file/272/download (accessed 28 October 2019) [in English].

9. Strategic framework "Education and Training 2020" (ET2020) - [Electronic resource] - Access mode: http://europa.eu/legislation_summaries/education_training_youth/general_framework/ef0016en.htm (accessed 30 October 2019) [in English].

Стаття надійшла до редакції 16.11.2019 р.

УДК 331.103 .3

Устіловська Анастасія, аспірант, викладач,

Харківський національний університет будівництва та архітектури, кафедра економіки,

м. Харків, ORCID ID 0000-0002-9297-7614 e-mail: ustilovskaya.an@ukr.net

https://doi.org/10.29038/2411-4014-2019-04-100-108

\section{ФОРМУВАННЯ ІННОВАЦЙНИХ МЕТОДІВ УПРАВЛІННЯ ПЕРСОНАЛОМ У РОЗРІЗІ ПРАКСЕОЛОГІЧНОГО ПІДХОДУ}

Як відомо, один з основних ресурсів та джерелом отримання вигод для підприємства $є$ його персонал, та належне його функціонування, в цілому, не можливе без впливу на нього з боку керівництва, що й стало запорукою створення системи управління персоналом. Комплексне поняття «управління персоналом» вказує на те, що процес впливу на працівників можливе лише з використанням спеціальних засобів і методів. В сучасних умовах господарювання досить актуальними стають радикально нові, інноваційні методи управління, до яких також відносять праксеологічний підхід. В традиційні методи управління персоналом 3 огляду на праксеологічний підхід доцільне введення ще однієї складової «методи формування ефективної поведінки персоналу». 